\title{
Ekstraksi Gelatin dari Tulang Ikan Nila Merah (Oreochromis Niloticus) dengan Variasi Konsentrasi Asam Klorida (HCl)
}

(Extraction of Gelatin from The Bone of Oreochromis Niloticus with Variations of Hydrochloric Acid Concentration)

\author{
Nurul Diah Lestari ${ }^{1}$ dan Siti Fatimah ${ }^{2 *}$ \\ ${ }^{1,2}$ Program Studi Teknik Kimia, Fakultas Teknik, Universitas Muhammadiyah Surakarta - Jl. A. Yani, \\ Mendungan, Pabelan, Kec. Kartasura, Kabupaten Sukoharjo, Jawa Tengah 57169
}

\section{ARTICLE INFO}

\section{Article history}

Received : 12 Agustus 2021

Revised : 25 September 2021

Accepted : 30 September 2021

DOI :

https://doi.org/10.33366/rekabua na.v6i2.2704

Keywords :

gelatin; extraction; tilapia bone

*e-mail corresponding author : sf120@ums.ac.id

\section{ABSTRAK}

Gelatin merupakan protein dari tulang hewan, jaringan ikat putih, atau kolagen kulit. Setiap tahun jumlah impor gelatin dari beberapa negara semakin meningkat. Dengan adanya produksi gelatin dari tulang ikan nila dengan skala yang besar diharapkan dapat membantu meningkatkan perekonomian di Indonesia dan mengurangi jumlah impor gelatin. Tujuan dari penelitian ini adalah mengolah tulang ikan nila menjadi gelatin dengan penggunaan asam klorida guna menjadikannya sebagai bahan dasar pembuatan gelatin yang halal dan dapat dikonsumsi sehingga dapat mengurangi jumlah limbah tulang ikan nila. Konsentrasi asam klorida yang digunakan yaitu 4, 5, dan 6\% dalam 500 ml larutan. Konsentrasi asam klorida mempengaruhi hasil dari gelatin. Kualitas gelatin yang didapatkan telah memenuhi kriteria standar mutu gelatin nasional sehingga dapat dipakai untuk bahan baku makanan. Rendemen yang dihasilkan berkisar $1,56-3,13 \%$ sedangkan kadar air berkisar antara 6,7 - 12,17 \%, kadar abu $1,75-2,52 \%$, dan $\mathrm{pH} 4,12-5,04$.
\end{abstract}

\section{PENERBIT}

\section{UNITRI PRESS}

Jl. Telagawarna, TlogomasMalang, 65144, Telp/Fax: $0341-565500$

\section{cc) (7) (2)}

This is an open access article under the Creative Commons Attribution-ShareAlike 4.0 International License. Any further distribution of this work must maintain attribution to the author(s) and the title of the work, journal citation and DOI. CC-BY-SA

\section{ABSTRACT}

Gelatin is a protein from animal bones, white connective tissue, or skin collagen. Every year the number of imports of gelatin from several countries is increasing. With the production of gelatin from tilapia bones on a large scale, it is hoped that it can help improve the economy in Indonesia and reduce the number of gelatin imports. The purpose of this study was to process tilapia bone into gelatin using hydrochloric acid to make it the essential ingredient for making gelatin which is halal and can be consumed to reduce the amount of tilapia bone waste. The concentrations of hydrochloric acid used were 4, 5, and 6\% in $500 \mathrm{ml}$ of solution. The concentration of hydrochloric acid affects the yield of gelatin. The quality of gelatin obtained has met the criteria of national gelatin quality standards to be used for food raw materials. The resulting yield ranges from $1.56-3.13 \%$, while the water content ranges from 6.7 $12.17 \%$, ash content from $1.75-2.52 \%$, and $\mathrm{pH} 4.12-5.04$.

Cara Mengutip : Lestari, N. D., Fatimah, S. (2021). Ekstraksi Gelatin dari Tulang Ikan Nila Merah (Oreochromis

Niloticus) dengan Variasi Konsentrasi Asam Klorida (HCl). Reka Buana : Jurnal Ilmiah Teknik Sipil dan Teknik Kimia, 6(2), 198-206. doi:https://doi.org/10.33366/rekabuana.v6i2.2704 


\section{PENDAHULUAN}

Gelatin merupakan protein dari tulang hewan, jaringan ikat putih, atau kolagen kulit yang didapatkan dari proses hidrolisis parsial kolagen. Gelatin dapat larut suhu panas, termasuk dalam air panas, kemudian apabila mendingin akan memiliki tekstur seperti gel [1]. Gelatin memiliki sifat bisa larut dalam air yang bersuhu panas dan akan berubah menjadi gel apabila berada pada air yang bersuhu dingin berasal dari sifat gelatin itu sendiri. Massa molekul yang terdapat dalam gelatin berkisar $20.000 \mathrm{~g} / \mathrm{mol}-$ $250.000 \mathrm{~g} / \mathrm{mol}[2]$.

Kolagen menjadi penyusun struktur komponen utama yang berada pada serat-serat jaringan pengikat. Ikan memiliki banyak kandungan kolagen. Pelarut asam maupun alkali dapat melarutkan kolagen, oleh karena itu kedua pelarut ini dapat digunakan untuk memproduksi gelatin dari tulang ikan [3].

Berbagai industri menggunakan gelatin dalam proses produksinya, misalnya dalam industri pangan yang menggunakan gelatin untuk membuat marshmallow. Biasanya gelatin digunakan dalam pembuatan marshmallow untuk medapatkan tekstur yang kenyal [4], industri kosmetik, industri farmasi yang menggunakan gelatin untuk membuat cangkang kapsul, mikroenkapsulasi, dan pengikat tablet. Biasanya cangkang kapsul yang dibuat dari gelatin ini berbahan dasar sapi atau babi [5]. Oleh karena itu penggunaan tulang ikan dapat menjadi alternatif pengganti bahan baku pembuatan cangkang kapsul yang halal.

Setiap tahun jumlah impor gelatin dari beberapa negara semakin meningkat. Dengan adanya produksi gelatin dari tulang ikan nila dalam skala yang besar diharapkan dapat membantu meningkatkan perekonomian di Indonesia dan mengurangi jumlah impor gelatin. Tulang ikan dapat dikategorikan sebagai limbah yang banyak dibuang oleh masyarakat, padahal memiliki nilai ekonomis yang tinggi, jumlahnya juga tersedia dengan jumlah sangat banyak. Tulang ikan nila dapat diproses menjadi gelatin dikarenakan memiliki harga yang murah dan dapat meningkatkan profit pada pengelola limbah industri perikanan dan masyarakat [6].

Telah banyak dilakukan oleh penelitian sebelumnya yang memanfaatkan tulang ikan sebagai bahan dalam pembuatan, misalnya penelitian yang dilakukan oleh Bhernama et al (2020) dengan memanfaatkan tulang ikan kakap menggunakan metode asam, gelatin yang dihasilkan telah memenuhi standar mutu nasional dengan konsentrasi asam klorida 7\% rendemen yang dihasilkan yaitu 1,90\%, kadar air sebesar 10,16\%, dan kadar abu sebesar 3\% [7]. Ridhay et al (2016) memanfaatkan tulang ikan cakalang dengan metode asam diperoleh hasil gelatin dengan rendemen tertinggi yaitu pada larutan $\mathrm{H}_{3} \mathrm{PO}_{4} 5 \%$ sebesar $14,66 \%$ dan memiliki kadar air sebesar 6,16\%, kadar abu 2,60\%, gelatin tersebut sudah memenuhi baku mutu nasional [8]. Panjaitan (2016) menggunakan tulang ikan tuna dengan metode asam, rendemen yang dihasilkan sebesar 5,03\%, kadar air 8,59\%, dan kadar abu 8,02\% dari konsentrasi asam klorida 3\% [9]. Mahmuda et al (2018) memanfaatkan tulang ikan belida dengan metode asam diperoleh gelatin yang sesuai dengan gelatin komersil, hasil rendemen tertinggi sebesar $8,8 \%$ dengan konsentrasi asam klorida 5\%, mengandung kadar air 2,14\% dan kadar abu 
2,81\% [10]. Jaya dan Rochyani (2020) menggunakan ikan gabus melalui metode asam menggunakan beberapa jenis asam, hasil terbaik terdapat menggunakan asam sitrat dengan rendemen $6 \%$, kadar air 9,21\%, dan pH 6 [11].

Berdasarkan dari beberapa penelitian di atas, maka tujuan dari penelitian ini adalah mengolah tulang ikan nila menjadi gelatin dengan metode asam guna menjadikan tulang ikan nila sebagai bahan baku pembuatan gelatin yang halal sehingga dapat mengurangi jumlah limbah tulang ikan nila.

\section{METODE PENELITIAN}

\subsection{Alat}

Alat yang dipakai untuk proses penelitian ini yakni : alat pencuci, alat pengukus, aluminium foil, desikator, erlenmeyer, gelas beker, gunting, kaca arloji, kertas saring, neraca analitik, oven, pengaduk, pipet volume, saringan, termometer, wadah plastik, waterbath.

\subsection{Bahan}

Bahan yang digunakan dalam penelitian yaitu : aquades, asam klorida $37 \%$, kertas $\mathrm{pH}$, tulang ikan nila merah yang memiliki nama latin Oreochromis niloticus, didapat dari desa Nganjat, Jawa Tengah. Di dalam tulang ikan nila terdapat kandungan air sebanyak $79 \%$, protein $13 \%$, karbohidrat 4\%, dan abu $1 \%$ [12].

\subsection{Prosedur Kerja}

\subsubsection{Degreasing (Pembersihan sisa lemak dan daging)}

Siapkan air mendidih kemudian rendam tulang ikan selama $1 / 2$ jam sambil terus diaduk. Kemudian diangkat dan ditiriskan, lalu potong seukuran kurang lebih $2 \mathrm{~cm}$, lalu dikeringkan dengan diangin-anginkan.

\subsubsection{Demineralisasi}

Siapkan tulang ikan sebanyak 100 gram kemudian direndam menggunakan larutan asam klorida $(4,5$, dan $6 \%$ ) didalam tempat yang bersifat tahan asam dengan perbandingan antara larutan asam : tulang ikan 3:1 selama 48 jam sehingga akan menghasilkan zat bernama osein. Osein dibilas hingga memperoleh $\mathrm{pH}$ netral

\subsubsection{Ekstraksi}

Proses setelahnya adalah memasukan osein ke dalam alat erlenmeyer kemudian tambahkan aquadest dengan perbandingan $1: 3$. Kemudian dilakukan ekstraksi selama 6 jam menggunakan alat waterbath dengan suhu $70^{\circ} \mathrm{C}$. Kemudian keringkan ekstrak gelatin menggunakan oven, setelah kering maka gelatin dihaluskan, kemudian analisis dan hitung nilai rendemennya.

\subsubsection{Karakterisasi}

Pada setiap perlakuan di analisis beratnya menggunakan neraca analitik. Setelah itu sampel di uji rendemen dengan cara membandingkan berat antara gelatin yang dihasilkan dengan berat bahan baku. Kemudian di uji kadar air yang diperoleh dari hasil 
pemanasan yang dilakukan secara bertahap pada suhu dan waktu tertentu sehingga diperoleh bobot berat yang konstan, lalu di uji kadar abu dengan cara mengabukan sampel. Selain itu dilakukan uji nilai $\mathrm{pH}$ dan uji organoleptik.

\subsubsection{Diagram Alir}

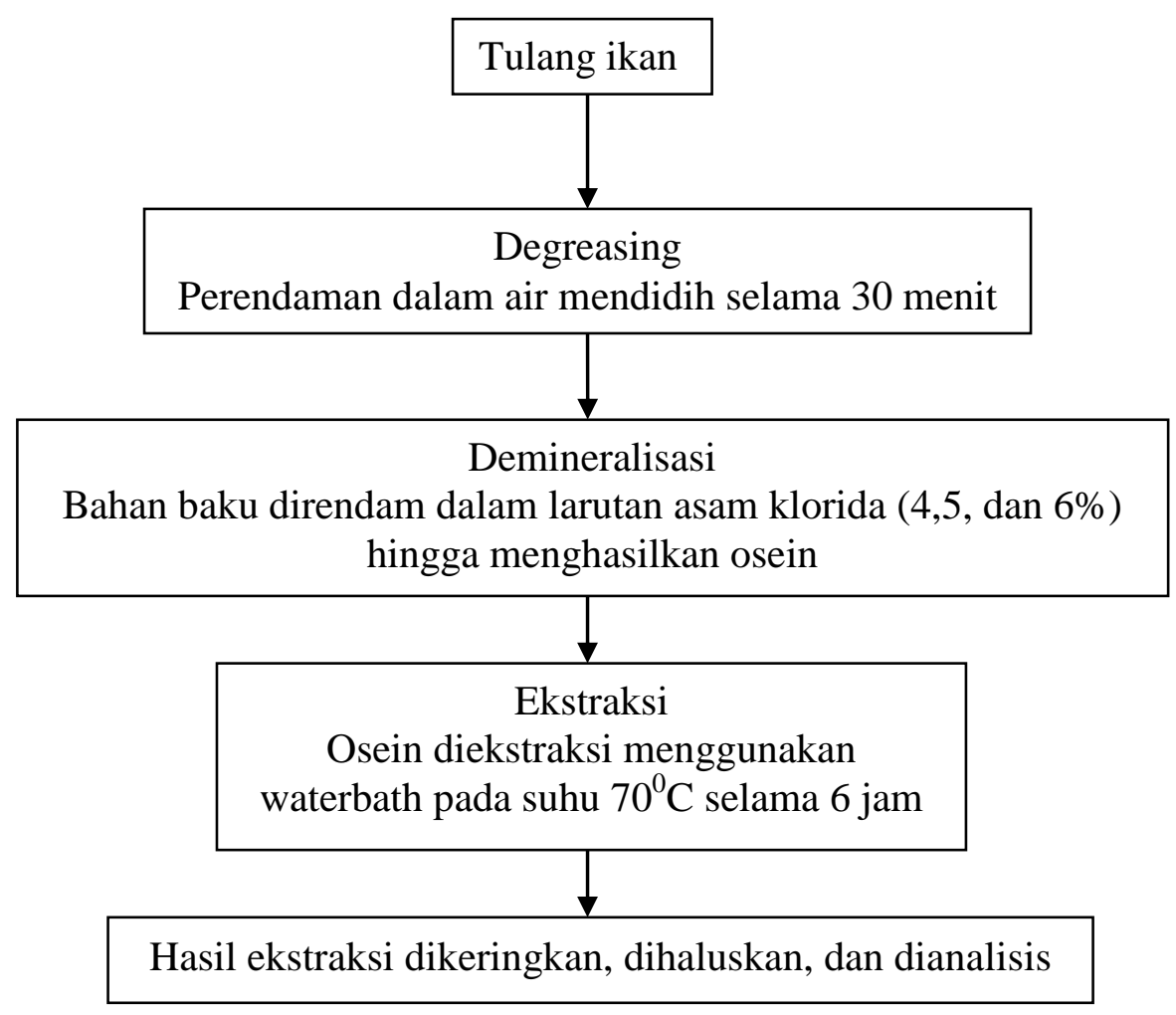

Gambar 1. Diagram alir proses pembuatan gelatin

\section{HASIL DAN PEMBAHASAN}

Penelitian ini dimulai dari pencucian bahan baku hingga bersih kemudian dikukus selama kurang lebih 30 menit untuk menghilangkan sisa lemak yang melekat di tulang ikan. Kemudian tulang ikan yang bersih direndam dalam larutan asam klorida dengan variasi 4,5 , dan $6 \%$ v/v selama 48 jam sampai menghasilkan osein. Setelah osein terbentuk, tulang ikan kemudian dicuci dan dibilas hingga mendapatkan $\mathrm{pH}$ netral. Osein kemudian diekstrak dalam waterbath dan ditambahkan aquadest dengan perbandingan osein dan aquadest $1: 3$ pada suhu $70^{\circ} \mathrm{C}$ selama 7 jam. Hasil ekstrak yang diperoleh kemudian dihaluskan dan dianalisis karakteristiknya.

\subsection{Rendemen}

Metode suatu perlakuan pada produksi gelatin dapat dikatakan efisien apabila nilai rendemen yang dihasilkan semakin tinggi[13]. Nilai rendemen gelatin dipengaruhi oleh segar atau tidaknya ikan yang akan diolah serta tempat penyimpanan ikan yang tepat [14]. Berdasarkan hasil percobaan, dapat dibuat grafik pengaruh konsentrasi asam klorida terhadap rendemen gelatin seperti pada gambar 1 . 


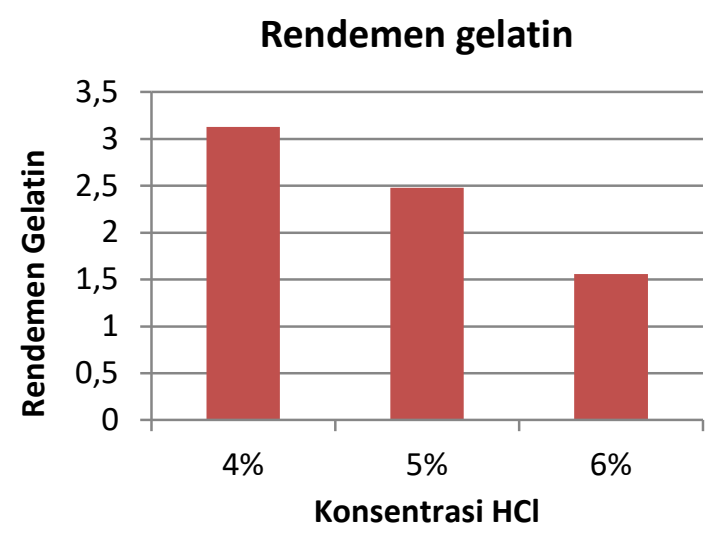

Gambar 2. Grafik pengaruh konsentrasi HCl terhadap rendemen gelatin

Berdasarkan grafik (gambar 2) diperoleh nilai rendermen sebesar 1,56-3,13\%, ini menunjukkan bahwa penggunaan asam klorida berpengaruh terhadap rendemen gelatin. Semakin tinggi konsentrasi asam klorida yang digunakan, maka semakin tinggi rendemen yang dihasilkan. Rendemen terbaik terjadi pada gelatin dengan konsentrasi $4 \%$. Pada penelitian terjadi penurunan dikonsentrasi $5 \%$ dan $6 \%$, ini dipengaruhi oleh tingginya konsentrasi asam klorida sehingga memungkinkan terjadinya hidrolisis lanjutan. Hal tersebut terjadi akibat ossein yang dihasilkan terlalu mudah hancur sehingga mudah larut bersama dengan air ketika proses penetralan $\mathrm{pH}$. Penggunaan asam klorida yang tinggi dalam rendemen menyebabkan putusnya triple heliks kolagen menjadi gelatin. Reaksi konversi kolagen menjadi gelatin yang terjadi yaitu sebagai berikut [15] :

$$
\begin{array}{ccc}
\mathrm{C}_{102} \mathrm{H}_{149} \mathrm{~N}_{31} \mathrm{O}_{38}+\mathrm{H}_{2} \mathrm{O} & \text { Gelatin } \\
\text { Kolagen } & \text { Air } & \mathrm{C}_{102} \mathrm{H}_{151} \mathrm{~N}_{31} \mathrm{O}_{39}
\end{array}
$$

\subsection{Kadar air}

Kadar air menjadi indikator penting dalam mempengaruhi usia penyimpanan suatu produk makanan. Usia produk makanan dipengaruhi oleh aktivitas metabolisme, yang mana kadar air akan memilkiki pengaruh pada aktivitas metabolisme tersebut salah satunya adalah aktivitas mikroba, enzim dan aktivitas kimiawi lainya yang menyebabkan terjadinya proses pembusukan dan reaksi non-enzimatis yang menyebabkan perubahan nilai gizi dan sifat organoleptik.

Air menjadi komponen yang penting pada suatu bahan makanan. Air yang dimaksud bisa berupa komponen ekstraseluler atau intraseluler dari sebuah produk [16]. Tampilan makanan, cita rasa, tekstur, dan kualitas bahan pangan sangat dipengaruhi oleh tinggi rendahnya kandungan kadar air yang ada pada bahan makanan [17].

Berdasarkan hasil percobaan, dapat dibuat grafik pengaruh konsentrasi asam klorida terhadap kadar air seperti pada gambar 3. 


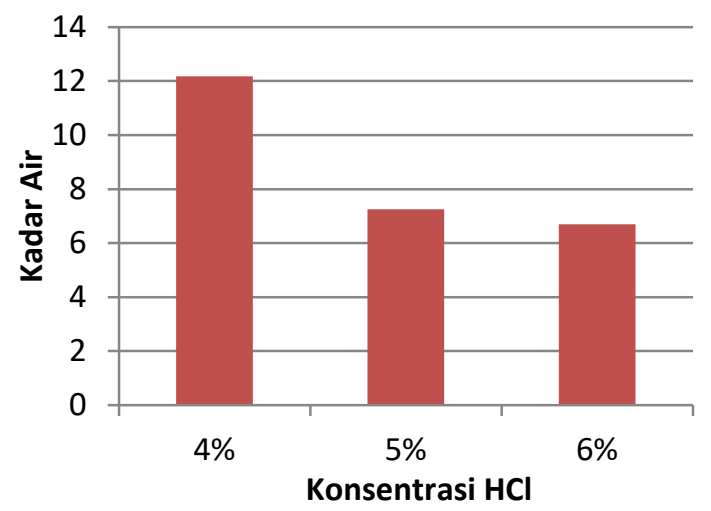

Gambar 3. Grafik pengaruh konsentrasi HCl terhadap kadar air gelatin

Berdasarkan grafik (gambar 3), kadar air yang diperoleh pada gelatin tulang ikan nila merah yaitu $6,7-12,17 \%$. Hasil tersebut telah memenuhi syarat baku mutu sesuai dengan Standar Nasional Indonesia (SNI) yaitu maksimal 16\%. Tulang ikan nila memiliki kadar air sebesar 79,44\% ini menunjukan bahwa kadar air sebelum proses ekstraksi sangat tinggi jika dibandingkan dengan kadar air sesudah proses ekstraksi. Kadar air tertinggi terdapat pada larutan asam klorida dengan konsentrasi $4 \%$ dan kadar air terendah pada konsentrasi 6\%. Perbedaan nilai tersebut dipengaruhi oleh penggunaan asam klorida dengan konsentrasi yang berbeda dalam mengisolasi kolagen tulang ikan nila menjadi gelatin. Sifat dan kemampuan bahan baku dalam menyerap air akan mempengaruhi tinggi rendahnya kadar air, kemudian proses pengeringan yang dilakukan juga akan mempengaruhi kadar air [8].

\subsection{Kadar abu}

Kadar abu merupakan salah satu metode pengujian untuk mengetahui kualitas dari suatu rendemen. Tujuannya adalah mengindikasikan kandungan mineral dan kemurnian suatu bahan dimana kandungan yang terdapat dalam bahan pangan terdiri dari $96 \%$ bahan organik dan air, sedangkan 4\% lainnya berupa unsur mineral [18].

Berdasarkan hasil percobaan, dapat dibuat grafik pengaruh konsentrasi asam klorida terhadap kadar abu seperti pada gambar 4.

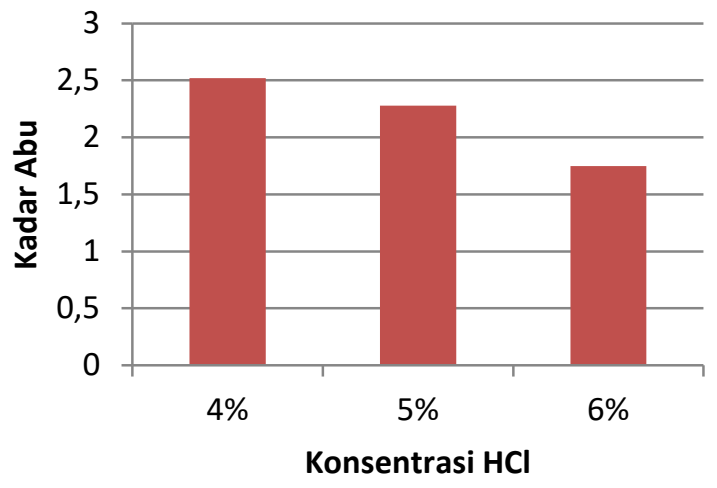

Gambar 4. Grafik pengaruh konsentrasi HCl terhadap kadar abu gelatin 
Berdasarkan grafik (gambar 4), didapatkan kadar abu pada gelatin tulang ikan nila merah berkisar dari $1,75-2,52 \%$. Hasil yang diperoleh telah memenuhi Standar Nasional Indonesia (SNI) yaitu maksimal 3,25\%. Semakin tinggi konsentrasi asam yang diberikan, maka semakin rendah nilai kadar abu yang dihasilkan. Hal ini dipengaruhi oleh proses demineralisasi. Proses demineralisasi berperan penting dalam menentukan kadar abu dalam suatu bahan pangan. Pada saat proses berlangsung, asam klorida akan bereaksi dengan kalsium fosfat sehingga menghasilkan garam kalsium dan ossein akan terbentuk. Persamaan reaksi yang terjadi yaitu sebagai berikut [19].

$$
\mathrm{Ca} 3(\mathrm{PO} 4) 2+6 \mathrm{HCl} \longrightarrow 3 \mathrm{CaCl} 2+2 \mathrm{H} 3 \mathrm{PO} 4
$$

\section{Kalium fosfat Asam klorida Kalsium klorida Asam fosfat}

\subsection{Nilai pH}

Nilai $\mathrm{pH}$ juga merupakan salah satu parameter penting dalam pengujian karena digunakan untuk mengukur derajat keasaman gelatin yang dihasilkan. Berdasarkan hasil percobaan, dapat dibuat grafik pengaruh konsentrasi asam terhadap nilai $\mathrm{pH}$ seperti pada gambar 5 .

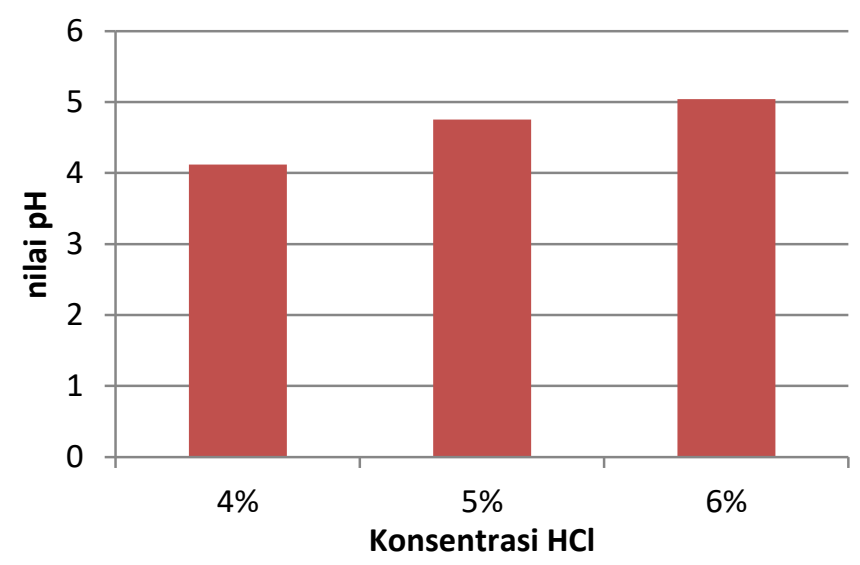

\section{Gambar 5. Grafik pengaruh konsentrasi HCl terhadap kadar abu gelatin}

Berdasarkan grafik (gambar 5), $\mathrm{pH}$ gelatin yang diperoleh yaitu 4,12 - 5,04. Hasil tersebut telah memenuhi baku mutu gelatin menurut Standar Nasional Indonesia (SNI) yaitu maksimal $6 \%$. Pada gambar 5 dapat diketahui bahwa $\mathrm{pH}$ yang tertinggi yaitu pada konsentrasi asam klorida $6 \%$ dan terendah $4 \%$. Ini menunjukkan bahwa penggunaan asam klorida yang semakin tinggi menyebabkan semakin tinggi pula $\mathrm{pH}$ yang diperoleh.

\subsection{Uji Organoleptik}

Selain itu dilakukan uji organoleptik meliputi warna dan bau yang melibatkan 6 orang. Hasil yang diperoleh dari warna gelatin yaitu dengan konsentrasi $4 \%$ berwarna kuning pucat, $5 \%$ berwarna kuning, dan $6 \%$ berwarna kuning. Menurut SNI, konsentrasi $4 \%$ sesuai dengan baku mutu SNI yaitu tidak berwarna hingga kuning pucat. Untuk konsentrasi 5\% dan 6\% tidak sesuai dengan baku mutu SNI karena hasil yang diperoleh berwarna kuning. Sedangkan untuk bau gelatin, semua perlakuan menghasilkan bau amis, tingkat keamisan dari yang amis sampai yang paling amis secara berurut yaitu 
sampel dengan konsentrasi 6\%,5\%,4\%. Hal ini tentu tidak sesuai dengan baku SNI yaitu gelatin berbau normal (dapat diterima konsumen). Gelatin yang berbau amis disebabkan oleh adanya urea yang mudah terurai menjadi ammonia [20]. Untuk menghilangkan bau amis yang disebabkan oleh adanya urea, maka dibutuhkan teknologi yang mampu menghilangkan bau amis tersebut tanpa merusak hasil akhir produk.

Secara keseluruhan dapat dikatakan bahwa sebagian besar uji karakterisasi gelatin yang telah dilakukan sudah memenuhi standar baku mutu nasional Indonesia dan dapat digunakan sebagai bahan baku pangan.

\section{KESIMPULAN}

Berdasarkan penelitian, tulang ikan dapat dimanfaatkan sebagai media pembuatan gelatin karena memiliki kandungan kolagen yang bisa dihidrolisis oleh air menggunakan suhu serta dilakukan pada kondisi yang tepat. Dari pengujian terhadap tulang ikan nila diperoleh hasil bahwa kualitas gelatin telah memenuhi kriteria standar mutu gelatin nasional sehingga bisa dipakai untuk bahan baku pangan. Penggunaan asam klorida dapat mempengaruhi rendemen gelatin. Rendemen gelatin akan meningkat jika jumlah konsentrasi asam klorida yang digunakan banyak. Rendemen yang didapatkan berkisar 1,56-3,13\%. Untuk uji karakteristik diperoleh kadar air berkisar antara 6,7 - 12,17 \%, kadar abu berkisar 1,75-2,52 \%, nilai pH berkisar 4,12- 5,04 \%. Dan untuk uji organoleptik diperoleh hasil bahwa sampel mengandung bau amis yang tidak sesuai dengan standar mutu gelatin sedangkan untuk warna yang sesuai dengan standar mutu gelatin yaitu sampel dengan konsentrasi $4 \%$.

\section{DAFTAR PUSTAKA}

[1] Dirjen POM, Farmakope Indonesia, 4th ed. Jakarta: Departemen Kesehatan Republik Indonesia, 1995.

[2] A. L. Parker, Principles of Biochemistry. Maryland: Worth Publisher, Inc., Sparkas, 1982.

[3] N. Suryani, F. Sulistiawati, and A. Fajriani, "Kekuatan gel gelatin tipe B dalam formulasi granul terhadap kemampuan mukoadhesif," Makara Kesehat., vol. 13, no. 1, pp. 1-4, 2009.

[4] R. Cahyaningrum, K. K. Safira, G. N. Lutfiyah, S. I. Zahra, A. A. Rahasticha, and N. Aini, "POTENSI GELATIN DARI BERBAGAI SUMBER DALAM MEMPERBAIKI KARAKTERISTIK MARSHMALLOW: REVIEW," Pas. Food Technol. J. (PFTJ, vol. 8(2), pp. 38-44, 2021.

[5] L. G. Febriana, N. A. S. P. H. Stannia, A. N. Fitriani, and N. A. Putriana, "Potensi Gelatin dari Tulang Ikan sebagai Alternatif Cangkang Kapsul Berbahan Halal : Karakteristik dan Pra Formulasi," Farmasetika, vol. 6(3), pp. 223-233, 2021.

[6] W. N. Huda, W. Atmaka, and E. Nurhartadi, "Kajian karakteristik fisik dan kimia gelatin ekstrak tulang kaki ayam (Gallus gallus bankiva) dengan variasi lama perendaman dan konsentrasi asam," J. Teknosains Pangan, vol. 2, no. 3, 2013.

[7] B. G. Bhernama, R. S. Nasution, and S. U. Nisa, "EKSTRAKSI GELATIN DARI 
TULANG IKAN KAKAP PUTIH (Lates calcarifer) DENGAN VARIASI KONSENTRASI ASAM HCl," J. Sains Nat. Univ. Nusa Bangsa, vol. 10(2), pp. 43$54,2020$.

[8] A. Ridhay, Musafira, Nurhaeni, Nurakhirawati, and N. B. Khasanah, "PENGARUH VARIASI JENIS ASAM TERHADAP RENDEMEN GELATIN DARI TULANG IKAN CAKALANG (Katsuwonus pelamis)," J. Ris. Kim. Kovalen, vol. 2(2), pp. 44-53, 2016.

[9] T. F. C. Panjaitan, “OPTIMASI EKSTRAKSI GELATIN DARI TULANG IKAN TUNA (Thunnus albacares)," J. Wiyata, vol. 3(1), pp. 11-16, 2016.

[10] E. Mahmuda, N. Idiawati, and M. A. Wibowo, "EKSTRAKSI GELATIN PADA TULANG IKAN BELIDA (Chitala lopis) DENGAN PROSES PERLAKUAN ASAM KLORIDA,” J. Kim. Khatulistiwa, vol. 7(4), pp. 114-123, 2018.

[11] F. M. Jaya and N. Rochyani, "Ekstraksi Gelatin Tulang Ikan Gabus (Channa striata) dengan Variasi Asam yang Berbeda pada Proses Demineralisasi," J. Perikan. DAN Kelaut., vol. 25(3), pp. 201-207, 2020.

[12] S. R. Suyanto, Nila. Jakarta: PT Penebar Swadaya, 1994.

[13] Irawaty, Pengaruh Penambahan Konsentrasi Asam Asetat pada Pembuatan Gelatin dari Ikan Gurami (Osphronemus gouramy lac). Jakarta, 2005.

[14] T. Paul, Islamic Branding and Marketing. Singapura: John Wiley and Sons, 2016.

[15] P. P. Dian, E. Darmawan, and Tjahyono, "Isolasi dan Sintesis Gelatin Sisik IkanKakap Putih (Lates carcarifer) Berikatan Silang dengan Teknik Industri Irradiasi Gamma," J. Sains Mater. Indones., vol. 14(1), pp. 40-44, 2012.

[16] M. Benion, The Science of Food. New York: John Wiley and Sons, 1980.

[17] M. A. Haris, "Pemanfaatan limbah tulang ikan nila (Oreochromis niloticus) sebagai gelatin dan pengaruh lama penyimpanan pada suhu ruang," 2008.

[18] D. Andriani, "Pengolahan Rumput Laut (Eucheuma cottonii) Menjadi Tepung ATC (Alkali Treated Cottonii Carrageenophyte) dengan Jenis dan Konsentrasi Larutan Alkali yang Berbeda," Skripsi. Univ. Hasanuddin, 2006.

[19] S. Almatsier, Prinsip Dasar Ilmu Gizi. Jakarta: PT Gramedia Pustaka Utama, 2003.

[20] N. Surono, D. Djazuli, Budiyanto, Widarto, Ratnawati, and Sugiran, Penerapan Paket Teknologi Pengolahan Gelatin dari Ikan Cucut. Jakarta: Laporan BBPMHP, 1994. 